УДК 347.73

DOI https://doi.org/10.32837/apdp.v0i85.1864

\title{
І.Я.Олендер
}

\section{ПРАВОВІ КОНСТРУКЦІЇ ТА ПІДХОДИ, СПРЯМОВАНІ НА УСУНЕННЯ ПОДВІЙНОГО ОПОДАТКУВАННЯ}

Постановка проблеми. Подвійне оподаткування є негативним явищем у податкових відносинах, спричиненим існуванням у податковому законодавстві суперечностей, які підлягають усуненню. При цьому для уникнення подвійного оподаткування необхідним є вироблення теоретичних підходів і правових конструкцій, які мають на меті усунення існуючих у податковому законодавстві розбіжностей. Визначення правових конструкцій і підходів, спрямованих на усунення явища подвійного оподаткування, може сприяти подоланню негативних явищ, спричинених подвійним оподаткуванням.

Аналіз останніх досліджень і публікацій. Теоретичним підгрунтям для цієї статті стали праці вітчизняних та іноземних вчених-юристів: Helvering v. Gregory, A. Sydney, Beck David, Hartman Dennis, M.M. Агаркова, 0.0. Головашевич, В.Г. Климентьева, И.И. Кучеровова, М.П. Кучерявенко, Н.С. Малеина, А.А. Малиновского, В.П. Панова, С.Г. Пепеляева, С. Погребняк, С.Н. Савсерис, Д.Г. Черник та інших. При цьому варто звертати увагу на особливості існуючих правових конструкцій і підходів до усунення подвійного оподаткування з огляду на тривалий розвиток податкових відносин.

Метою статті є визначення суті підходів і правових конструкцій, спрямованих на усунення негативних виявів подвійного оподаткування.

Виклад основного матеріалу дослідження. Існують три підходи, які використовуються для виключення обов'язку сплати податків з одного і того ж об'єкта оподаткування. Перший підхід передбачає усунення подвійного оподаткування за допомогою використання виключно внутрішньодержавних ресурсів. В рамках внутрішнього законодавства застосовуються два основних методи усунення подвійного оподаткування: податкове звільнення і податкове відрахування.

Податкове звільнення (tax exemption) передбачає повне виключення з оподатковуваної бази доходів, які були отримані резидентом за кордоном. Розрізняються два способи його застосування: без прогресії - держава-резидент дозволяє вирахувати з податкової бази збитки, понесені в інших країнах; із прогресією, коли збитки можна враховувати при визначенні ставки оподаткування сукупного доходу. Привабливість подібного варіанту усунення подвійного оподаткування полягає в тому, що цей метод дозволяє повністю виключити можливість подвійного оподаткування.

Сучасні вітчизняні вчені виділяють такі переваги використання цього методу:

1) забезпечується принцип нейтральності капіталу, що сприяє підвищенню конкурентоспроможності своїх резидентів, які здійснюють комерційну діяльність за кордоном; 
2) для національних податкових адміністрацій цей метод не викликає серйозних організаційних проблем при податковому адмініструванні у зв'язку з тим, що він грунтується на обмеженні права держави на справляння податків з доходів своїх резидентів, отриманих ними в інших країнах;

3) платник податку отримує вигоду за допомогою зменшення податкового тягаря [1].

Однак у цього методу вирішення проблеми подвійного оподаткування $є$ i cepйозні недоліки. Так, держави, які мають у своєму податковому законодавстві подібний варіант, будуть нести суттєві бюджетні втрати при його реалізації; значно збільшується ризик того, що діяльність компаній буде переноситися в низькоподаткові території. Різні країни мають відмінності в порядку застосування методу звільнення в країні президентства, тому виділяються такі їх різновиди:

1) від оподаткування звільняються всі іноземні доходи;

2) припустиме виключення іноземних доходів у встановлених кількостях і межах;

3) виключення певних видів іноземних доходів;

4) податкова ставка калькулюється з обліку доходів, одержаних цими платниками податків в інших країнах [1].

Податкове вирахування (tax deduction) дає можливість зменшувати сукупну податкову базу на суму податків, сплачених платником податків за кордоном [1]. Подібний підхід має кілька недоліків: його односторонній характер передбачає частково або повністю відмову держави від своїх податкових претензій; не всі причини, внаслідок яких виникає подвійне оподаткування, підпадають під сферу дії внутрішнього законодавства (наприклад, проблема множинності резидентства).

Другий підхід грунтується на вирішенні проблеми подвійного оподаткування шляхом застосування міжнародного податкового судочинства. Проте компетенція існуючих міжнародних судів обмежена. Очевидно, що цей підхід не здатний повністю впоратися з проблемою подвійного оподаткування.

Третій підхід передбачає укладення державами угод про уникнення подвійного оподаткування. Ці угоди чітко визначають, які держави і в якому розмірі володіють правом або обов'язком стягувати податки за окремими категоріями доходів і майна. Цей підхід успішно застосовується більшістю країн світу за рахунок того, що саме він найбільше враховує фінансові інтереси не тільки держави, але і платника податків. Укладення між державами дво- і багатосторонніх угод про уникнення подвійного оподаткування є найефективнішим способом вирішення зазначеної проблеми, оскільки дозволяє усувати подвійне оподаткування за допомогою використання не тільки можливостей внутрішнього законодавства і власних ресурсів держави, а й забезпечує комплексний підхід до вирішення поставленого завдання.

В рамках угод про уникнення подвійного оподаткування здебільшого використовуються два основні способи вирішення проблеми подвійного оподаткування:

- залік податку, який був сплачений в одній державі-партнері за угодою, при визначенні розміру податку, що підлягає сплаті в іншій державі-партнері за угодою;

- звільнення від оподаткування в одній державі-партнері за угодою в разі, якщо податки з них були сплачені в іншій державі-партнері за угодою. 
Найпоширенішим способом запобігання подвійному оподаткуванню в рамках податкових угод є спосіб заліку. Згідно з міжнародною податковою практикою Російської Федерації особа, яка має постійне місцеперебування в одній державі-партнері за угодою, отримує дохід, який може оподатковуватися в іншій державі-партнері за угодою, сума податку з цього доходу, яка повинна бути сплачена в іншій державі, може бути вирахувана із суми податку, що стягується з цієї особи в першій державі.

Однак проблема подвійного оподаткування не є єдиною проблемою, з якою стикаються як платники податків, так і податкових органів. Інша проблема полягає в міжнародному ухилянні від сплати податків. Державні бюджети втрачають величезні обсяги податку на доходи фізичних і юридичних осіб, які підлягають сплаті, внаслідок переміщення доходу в низькоподаткові юрисдикції. Міжнародне ухиляння від сплати податку має місце як в результаті діяльності заможних індивідуальних інвесторів, так і міжнародних корпорацій.

Сучасні засади організації регулювання податкових відносин передбачають безумовне право платника податків використовувати всі доступні йому законні засоби для мінімізації податкових зобов’язань, що передбачає і більш вузьке право на податкове планування. Одним із найяскравіших рішень у прецедентному податковому праві стало положення: «Будь-хто може таким чином упорядкувати свої справи, щоб платити якнайменші податки. Ніхто не зобов'язаний діяти так, щоб скарбниця отримала найбільший зиск. Не існує навіть громадянського обов'язку збільшувати власні податки" [2, с. 7]. Відповідними судовими прецедентами в цій галузі стали - для Великої Британії Commissioners of Inland Revenue v. Duke of Westminster (1936), для Австралії-Jaques v. Federal Commissioner of Taxation (1924), для Бельгії - рішення Касаційного суду від 6 червня 1961 року.

Можна стверджувати, що, врегулювавши відповідні відносини за допомогою права, сторони стали заручниками правового механізму, при цьому одна з них отримала явну перевагу у праві тлумачити будь-яку неточність на власну користь. Як вказує відомий дослідник податкових правовідносин Віткрофт: «Жодна країна ще не змогла так сформулювати закони про оподаткування, щоб порядок підрахунку податкових зобов'язань був зрозумілим за будь-яких можливих обставин» [3]. Враховуючи об'єктивну недосконалість правового механізму, пов’язану й з обмеженими можливостями законодавчої техніки, правової доктрини та й права як суспільного регулятора, такий результат є можливим для нормального розвитку суспільних відносин та економіки.

Виходячи 3 того, що податкові правовідносини належать до публічних відносин, які регулюються імперативним методом, абстрактні приписи податкових норм можуть призвести до диктату держави. Визнання державою як владної сторони у податкових відносинах права особи на реалізацію власного інтересу в межах, не заборонених законом, є свідченням високого рівня розвитку правових відносин у суспільстві.

Показово, що ще в 1930 році Д. Гартмен, відомий правник, автор багатьох праць із податкового планування, у першому виданні свого популярного посібника «Уникнення оподаткування» підкреслював новизну цього поняття [4, с. 17]. І хоча 
перший судовий прецедент, що стосувався податкового планування у Сполучених Штатах Америки (United States v. Isham), мав місце ще 1873 року, як оформлений рух воно почало розвиватися лише в 30 -х роках XX століття.

Нині податкове планування динамічно змінюється, що передбачає корекцію поведінки як державних органів, так і платників. Причому дії спрямовуються як на досягнення рівності всіх перед законом (як державних органів, так і платників податків), так і рівності всіх платників у виникненні та розподіленні податкового обов'язку. Податкове планування залишається законним діянням платників податків, які відповідають принципам побудови системи оподаткування, що забезпечує їм визнання та захист з боку держави. Будь-які заперечення проти таких дій повинні доводитися в спеціалізованому суді.

Більшість із поточних юридичних засобів боротьби держави з неприйнятним уникненням оподаткування не є бездоганними з точки зору принципу верховенства права, який гарантує платникові податків регулювання податкових відносин виключно законодавчими актами та стабільність відповідних податкових зобов'язань. Виправданою є також необхідність виваженого підходу до призначення санкцій, які застосовуються до платника податків у випадку нечіткості положень чинного законодавства.

За відсутності роз'яснень з боку відповідних органів виконавчої влади такі неточності платник податків, з огляду на викладені вище засади правового регулювання податкових відносин, може використовувати на свою користь. Звідси виникає питання правомірності покарання законодавця, якому не вдалося сформулювати точний законодавчий припис, та логічності покладення на платника податків зобов'язання відшкодувати відповідні кошти без сплати будь-яких штрафних санкцій.

Висновки. Підходами до усунення подвійного оподаткування є його усунення за допомогою використання виключно внутрішньодержавних ресурсів, вирішення проблеми подвійного оподаткування шляхом застосування міжнародного податкового судочинства, укладення державами угод про уникнення подвійного оподаткування. Зважаючи на те, що податкові правовідносини належать до публічних відносин, врегульованих імперативним методом, використання абстрактних приписів податкових норм є не виправданим, адже наслідком використання таких норм може стати диктат держави. Натомість виправданою є необхідність виваженого підходу до призначення санкцій, які застосовуються до платника податків у випадку нечіткості положень чинного законодавства.

\section{Jimepamypa}

1. Кучеров И.И. Международное налоговое право М. : ЗАО «ЮрИнфоР», 2007.

2. Helvering v. Gregory (1934). Цитата подається за: Gutkin, A. Sydney, Beck, David, Tax Avoidance vs. Tax Evasion. New-York : The Ronald Press Company, 1958. C. 7.

3. GSA. Wheatcroft, The Interpretation of Taxation Laws With Special Reference to Form and Substance. 1965. vol La Cahiers de Droit Fiscal, 7.

4. Hartman Dennis. Tax Avoidance. Washington, D.C. : Legal Publishing Society, Inc., 1930. C. 17. 


\begin{abstract}
Анотація Стаття.

Олендер I. Я. Правові конструкції та підходи, спрямовані на усунення подвійного оподаткування. -

У науковій роботі досліджено подвійне оподаткування як негативне явище у податкових відносинах, спричинене існуванням у податковому законодавстві суперечностей, що підлягають усуненню. Встановлено необхідність вироблення теоретичних підходів і правових конструкцій, які мають на меті усунення існуючих у податковому законодавстві розбіжностей для усунення подвійного оподаткування. Автором визначено правові конструкції та підходи, спрямовані на усунення явища подвійного оподаткування. У статті проаналізовано праці вітчизняних і зарубіжних вчених з проблематики усунення явища подвійного оподаткування з огляду на тривалий розвиток податкових відносин.

Автор акцентує увагу на неприйнятності більшості з поточних юридичних засобів боротьби держави з неприйнятним уникненням оподаткування з точки зору принципу верховенства права, який гарантує платникові податків регулювання податкових відносин виключно законодавчими актами та стабільність відповідних податкових зобов'язань.

За результатами проведеного у науковій роботі дослідження встановлено наявність трьох найрозповсюдженіших підходів до усунення подвійного оподаткування: усунення подвійного оподаткування за допомогою використання виключно внутрішньодержавних ресурсів; вирішення проблеми подвійного оподаткування шляхом застосування міжнародного податкового судочинства; укладення державами угод про уникнення подвійного оподаткування. В межах останнього підходу виокремлено два основні способи вирішення проблеми подвійного оподаткування в рамках угод про уникнення подвійного оподаткування: залік податку, який був сплачений в одній державі-партнері за угодою, при визначенні розміру податку, що підлягає сплаті в іншій державі-партнері за угодою; звільнення від оподаткування в одній державі-партнері за угодою в разі, якщо податки з них були сплачені в іншій державі-партнері за угодою.

Наголошено на невиправданості використання абстрактних приписів податкових норм, адже наслідком використання таких норм може стати диктат держави. Автором вважає виправданою необхідність виваженого підходу до призначення санкцій, які застосовуються до платника податків у випадку нечіткості положень чинного законодавства.
\end{abstract}

Ключові слова: податкові відносини, податкове законодавство, усунення подвійного оподаткування, податкове судочинство, податкові угоди.

\title{
Summary
}

Olender I. Ya. Legal constructions and approaches aimed at elimination of double taxation. - Article.

The scientific work investigates double taxation as a negative phenomenon in tax relations, caused by the existence of contradictions in the tax legislation, which must be eliminated. The need to develop theoretical approaches and legal constructions aimed at eliminating the existing differences in tax legislation to eliminate double taxation has been established. The author identifies legal constructions and approaches aimed at eliminating the phenomenon of double taxation. The article analyzes the works of domestic and foreign scholars on the elimination of the phenomenon of double taxation in view of the ongoing development of tax relations.

The author emphasizes the inadmissibility of most of the current legal means of combating the state with unacceptable tax avoidance in terms of the rule of law, which guarantees the taxpayer the regulation of tax relations exclusively by legislation and the stability of relevant tax obligations.

According to the results of the research conducted in the scientific work, the existence of the three most common approaches to the elimination of double taxation, which include: elimination of double taxation through the use of exclusively domestic resources; solving the problem of double taxation through the application of international tax proceedings; conclusion by states of agreements on avoidance of double taxation. The latter approach identifies two main ways to address double taxation in double taxation agreements: offsetting tax paid in one partner country under the agreement when determining the amount of tax payable in another partner country under the agreement; exemption from taxation in one partner country under the agreement if the taxes from them were paid in another partner country under the agreement.

The unjustified use of abstract prescriptions of tax norms is emphasized, as the use of such norms may result in state dictates. The author considers justified the need for a balanced approach to the imposition of sanctions applied to the taxpayer in case of ambiguity of the current legislation.

Key words: tax relations, tax legislation, elimination of double taxation, tax litigation, tax agreements. 